Y. FENG, G, YAN, T, WANG, W. JIA, X, ZENG* J, SPERRY, Y, SUN, X. TANG, T. LEI,

L. LIN (XIAMEN UNIVERSITY, FUJIAN ENGINEERING AND RESEARCH CENTRE OF CLEAN AND HIGH-VALUED TECHNOLOGIES FOR BIOMASS, XIAMEN, AND HENAN KEY

LABORATORY OF BIOMASS ENERGY, P. R. OF CHINA; UNIVERSITY OF AUCKLAND, NEW ZEALAND)

$\mathrm{Cu}^{1}-\mathrm{Cu}^{0}$ Bicomponent CuNPs@ZIF-8 for Highly Selective Hydrogenation of Biomass Derived 5-Hydroxymethylfurfural Green Chem. 2019, 21, 4319-4323.

\section{Zeolitic Imidazole Framework Encapsulated Copper Nanoparticles for Hydrogenation of Aldehydes}

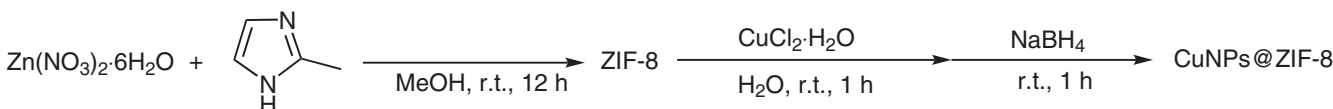

\title{
Category
}

Polymer-Supported

Synthesis

Key words

copper catalysis

hydrogenation

aldehydes

alcohols

nanoparticles

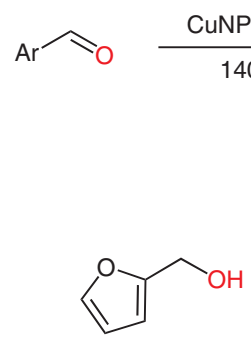

$99 \%$ yield<smiles>COc1ccc(CO)cc1</smiles><smiles>Cc1ccc(CO)o1</smiles>

$99 \%$ yield<smiles>CC(C)c1ccc(CO)cc1</smiles>

$98 \%$ yield
(2)

\section{8 examples} up to $99 \%$ yield

\section{Synfact of the}

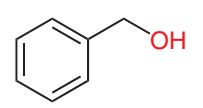

$99 \%$ yield

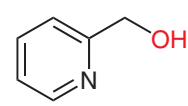

$99 \%$ yield
Significance: Copper nanoparticles encapsulated in a zeolitic imidazole framework (CuNPs@ZIF-8), prepared as shown in equation 1, catalyzed the hydrogenation of aromatic aldehydes with hydrogen gas to give the corresponding alcohols in yields of 94-99\% (eq. 2; 8 examples).
Comment: The CuNPs@ZIF-8 catalyst was characterized by means of XRD, XPS, AES, TEM, and HR-TEM analyses. In the hydrogenation of 5-(hydroxymethyl)furfural, the catalyst was recovered and reused four times without loss of its catalytic activity. 